\title{
DA FALÊNCIA À RECUPERAÇÃO JUDICIAL: DISTINÇÕES NOS PROCESSOS DE PEQUENA E GRANDE EMPRESA
}

\section{CÉSAR AUGUSTO SIMÕES RAMOS}

Acadêmico do curso de Direito - Instituto Superior de Ensino e Pesquisa - ISEPE. Guaratuba - PR. E-mail: augusto.roadie@outlook.com

\section{ALCELYR VALLE DA COSTA NETO}

Professor Orientador - Instituto Superior de Ensino e Pesquisa - ISEPE. Guaratuba PR. E-mail: avcostaneto@yahoo.com.br

\section{RESUMO}

O presente artigo tem como objetivo, analisar $\mathrm{O}$ acontecimento da recuperação judicial e as fases enfrentadas pelo empresário falido, fazendo um apanhado histórico de como surgiu o direito falimentar, desse modo, analisando os fatos marcantes de como se instituiu este direito tão importante para nossa legislação. Diante disso, entende-se que o tema ora trazido em tela, tem uma relevância significativa, pois, com o advento da Lei 11.101/05, a qual regula o direito de falência e do pedido de recuperação judicial da pequena e média empresa. Fazendo assim, uma analise das diversas formas e possibilidades para que empresário, seja ele de micro empresa ou empresas de grande porte, diferenciado-as cada qual com seu poder aquisitivo e espaço social, tem de se organizar para decretar sua Falência com a intenção de realizar o requerimento da Recuperação Judicial, tendo em vista, a grande dificuldade diante da complexidade que o assunto exige. Para tanto, elegeuse a seguinte problemática: quais são os processos pelos quais as grandes e pequenas empresas brasileiras passam para decretar suas falências e realizar pedido de recuperação judicial? A metodologia utilizada foi a pesquisa bibliográfica, com base 
Personalidade Acadêmica Homenageada:

Augustus B. Cochran III (Agnes Scott College)

nos principais doutrinadores desta área jurídica, bem como na lei e jurisprudência. Diante disso, tem-se como resultado preliminar que, as empresas de pequeno porte denominadas EPP (as quais se enquadram o micro empreendedor) bem como as empresas de médio porte, precisam cumprir com os mesmos requisitos e critérios apresentados na lei 11.101/05 para a elaboração do plano de recuperação. Isto se demonstra por vezes visto que, nem todos os pequenos empreendedores detêm os recursos e pessoal necessário para esta complexa tarefa, o que a coloca em pé de desigualdade perante a grande empresa, assim, verifica-se uma dificuldade maior para que o pequeno empresário falido consiga atender com toda a burocracia necessária para a apresentação de um plano de Recuperação Judicial.

PALAVRAS-CHAVE: Recuperação Judicial da Pequena Empresa; Recuperação da Empresa de Pequeno Porte; Falência da Pequena Empresa.

\section{REFERÊNCIAS}

ALMEIDA, Amador Paes de. Curso de Falência e Recuperação de Empresa, 26은 Edição, 2ํㅡㄹ tiragem, Editora Saraiva 2002;

GUSMÃO, Mônica, Lições de Direito Empresarial. $12^{\mathrm{a}}$ ed. Rio de Janeiro: Forense 2015;

REQUIÃO, Rubens. Curso de Direito Falimentar. Concordatas, crimes falimentares, intervenção e liquidação extrajudicial. V. 2ํ. 14를 Ed, São Paulo: Saraiva 1995;

RONCONI, Diego Richard - Falência e Recuperação de Empresa; Análise da utilidade social de ambos os institutos. 1ํㅡㄹ, Univale: Itajaí 2002; 